\title{
AMYLASE INHIBITION AND FREE RADICAL SCAVENGING ACTIVITIES OF WHITE TURMERIC EXTRACT AND FRACTIONS
}

\author{
[Penghambatan Enzim Amilase dan Penangkapan Radikal Bebas \\ dari Ekstrak dan Fraksi Kunir Putih]
}

\author{
Dwiyati Pujimulyani ${ }^{1) \star}$, Wisnu Adi Yulianto' ${ }^{1}$, Astuti Setyowati ${ }^{1)}$ \\ Seila Arumwardana ${ }^{2)}$, Annisa Amalia ${ }^{2)}$, Hanna Sari W. Kusuma ${ }^{2)}$, dan Ervi Afifah ${ }^{2)}$ \\ 1) Faculty of Agroindustry, University of Mercu Buana, Yogyakarta \\ 2) Aretha Medika Utama, Biomolecular and Biomedical Research Center, Bandung
}

Received September $17^{\text {th }} 2017$ / Accepted March $21^{\text {st }} 2018$

\begin{abstract}
Diabetes is the most common endocrinal disorder characterized by hyperglycemia and long-term complications. Recently, the development of antidiabetic drugs have focused on natural products with various mechanisms such as the inhibition of a-amylase. White turmeric (Curcuma mangga Val) from Zingeberaceae family has been reported to have antidiabetic activities, thus the aim of this study was to eva luate the effects of $C$. mangga extracts and fractions as antioxidant and antidiabetic agents through scavenging activities and inhibition of $\alpha$-amylase. In this study, the antidiabetic activities of four fractions of $C$. mangga extracts (water, hexane, ethyl acetate, butanol), a C. mangga extract and butylated hydroxytoluene/antioxidant standard were measured using $\alpha$-amylase activity assay, while the antioxidant activities of the fractions were measured using 2,2-diphenyl-1-picrylhydrazyl (DPPH) and 2,2'-azino-bis (3-ethylbenzothiazoline-6-sulfonic acid) (ABTS) as says. These fractions were also compared to an antidiabetic drug, acarbose, as a control and butylated hydroxytoluene (BHT), a synthetic antioxidant. For the antioxidant assay, the butanol fraction of $C$. mangga (BCM) showed the highest ABTS-reducing activity $\left(\mathrm{IC}_{50}=24.23\right.$ $\pm 2.77 \mu \mathrm{g} / \mathrm{mL}$ ), while with the DPPH assay, the ethyl acetate fraction (EACM) had the highest activity (IC 50 $=83.95 \pm 2.89 \mu \mathrm{g} / \mathrm{mL}$ ) as compared to the other fractions and C. mangga extract, but the activities were lower than that of BHT. For the antidiabetic assay, $C$. mangga extract (CME) had the highest $\alpha$-amylase inhibitory activity $\left(\mathrm{IC}_{50}=363.67 \mu \mathrm{g} / \mathrm{mL}\right)$ among other fractions, although lower than acarbose. Curcuma mangga fractions (BCM and EACM) had antioxidant activities, while C. mangga extract (CME) had a potential as an antidiabetic by in vitro studies. Further in vivo studies is needed to confirm these findings.
\end{abstract}

Keywords: amylase, antidiabetic, antioxidant, white turmeric

\begin{abstract}
ABSTRAK
Diabetes merupakan kelainan endokrin yang paling umum ditandai dengan hiperglikemia dan dalam jangka panjang terjadi komplikasi. Perkembangan ob at antidiabetes baru-baru ini ditekankan pada produk alami dengan berbagai mekanisme seperti menghambat $\alpha$-amilase. Kunir putih (Curcuma mangga Val.) yang merupakan famili dari Zingeberaceae telah dikenal memiliki aktivitas antidiabetes, sehingga penelitian ini bertujuan untuk mengevaluasi efek dari ekstrak dan fraksi C. mangga sebagai antioksidan dan antidiabetes melalui aktivitas pemerangkapan dan penghambatan $\alpha$-amilase. Pada penelitian ini, dilakukan uji aktivitas $\alpha$-amilase, dari empat fraksi kunir putih (air, heksana, etil asetat, butanol) dan ekstrak kunir putih, sedangkan aktivitas antioksidan dari fraksi tersebut diukur dengan 2,2-difenil-1-pikrilhidrazil (DPPH) dan 2,2'-azino-bis (3-ethylbenzothiazoline-6-sulphonic acid) (ABTS). Fraksi kunir putih juga dib andingkan dengan obat antidiabetes acarbose, sebagai kontrol dan Butylated hidroksitoluena (BHT) antioksidan sintesis sebagai pembanding. Pada uji antioksidan, fraksi butanol dari C. mangga (BCM) menunjukkan aktivitas reduksi ABTS paling tinggi $\left(I C_{50}=24,23 \pm 2,77 \mu \mathrm{g} / \mathrm{mL}\right)$, sedangkan pada uji $D P P H$, fraksi etil asetat (EACM) dari C. mangga memiliki aktivitas tertinggi $\left({ } C_{50}=83,95 \pm 2,89 \mu \mathrm{g} / \mathrm{mL}\right)$ dibandingkan dengan fraksi C. mangga yang lain dan ekstrak C. mangga (CME), namun tidak leb ih tinggi dibandingkan dengan standar antioksidan (BHT). Pada uji antidiab et, CME memiliki aktivitas tertinggi pada penghambatan a-amilase $\left(I C_{50}=363,67 \mu \mathrm{g} / \mathrm{mL}\right)$ dib andingkan dengan fraksi lain, namun tidak lebih tinggi dibandingkan dengan acarbose. Fraksi C. mangga (BCM dan EACM) memiliki aktivitas antioksidan, sementara itu CME memiliki potensi awal sebagai antidiabetes dan diperlukan pengujian lanjut dengan pengujian secara in-vivo.
\end{abstract}

Kata kunci: amilase, antidiabetes, antioksidan, kunir putih

*Corresponding Author:

Email: dw iyati2002@yahoo.com 


\section{INTRODUCTION}

Antidiabetic drugs aim to maintain blood glucose levels in the normal range and to reduce diabetes associated symptoms such as polyuria, ketoacidosis, weight loss, and dehydration (Derosa and Maffioli, 2012). Recently, several studies have been reported regarding therapies in diabetes that have $\mathrm{li}$ mited efficacy, limited tolerability and/or significant mechanism based side effects (Rotenstein et al., 2012). The drugs are also expensive and have several adverse effects that make the patients live more miserable.

ROS potentially contributes to type 2 diabetes mellitus (T2DM) via attacking the healthy body cells and damaging their functional and structural integrity, which consequently leads to many pathophysiological conditions (Betteridge, 2000). Oxidative stress is defined as an imbalance between the production of reactive oxygen species (ROS) and the detoxification of their harmful effects through antioxidants (Betteridge, 2000). The clinical studies in vivo or in vitro have been performed on natural products to evaluate their potential as antidiabetic agents. Most of the natural products including fruits, vegetables, mushrooms, nuts, natural beverages and oils attenuate the pathogenic factors of T2DM and enhance the expression of beneficial genes and proteins required to control T2DM (Alam et al., 2016).

In previous years, natural products exhibited promising results of T2DM management via inhibiting $\alpha$-amylase and $\alpha$-glucosidase, sodium dependent glucose transporters, gluconeogenic enzymes, aldose reductases, and advanced glycation end products (AGEs); increasing insulin secretion and activity, glucose uptake, and pancreatic $\beta$-cell protection; regulating glucose transporter 4 (GLUT4); reducing oxidative stress; and mimicking insulin action (Alam et al., 2016). The mechanism of acarbose are reversibly binds and inhibits the pancreatic $\alpha$ amylase and membrane bound intestinal $\alpha$ glucoside hydrolases to further inhibit the hydrolysis of complex carbohydrates into glucose in the small intestine. The side effects of acarbose can cause hepatitis, gastrointestinal side effects (flatulence and diarrhea), and its drug interactions can increase its hypoglycemic action (Alam et al., 2016). Therefore, it is needed to identify and explore the amylase inhibitors from natural sources having fewer side effects.

One of medical herbs that has high antioxidant is derived from Zingiberaceae family, which is Curcuma mangga (white turmeric). Phenolic compounds in C. mangga can induce glutation-S-transverase (GST) enzymes that play a role in detoxification in the body and can supress oxidative stress. Zingiberaceae family was demonstrated to have antidiabetic properties by inhibition of alphaglucosidase enzy- mes (Hasimun et al., 2016). Therefore, the purpose of this study was to evaluate the effect of $C$. mangga extract and fractions as an antioxidant and antidiabetic agent through scavenging activity and inhibition of $\alpha$-amylase.

\section{MATERIALS AND METHODS}

\section{Materials}

The plants of $C$. mangga were collected from the plantation in Yogyakarta, Special Region of Yogyakarta, Indonesia.

\section{Preparation of $C$. mangga extract}

Extraction was performed based on a maceration method (Widowati et al., 2014; Widowati et al., 2016). C. mangga was dried, blanched, and milled then soaked in $70 \%$ distillated ethanol and filtered every 24 hours until colorless filtrate was gained. Afterwards, the filtrate was evaporated to obtain ethanol extract using rotary evaporators (Stuart, RE 300). The C. mangga extract (CME) was stored at $20^{\circ} \mathrm{C}$.

\section{Fractionation of $C$. mangga ethanol extract}

Fractionation of $C$. mangga ethanol extract was done using modified partition (Widowati et al., 2011). C. mangga ethanol extract $(25 \mathrm{~g})$ was partitioned with $\mathrm{n}$-hexane and water (1:1), yielded a hexane fraction of $3.77 \mathrm{~g}(18.85 \%)$, the residue was partitioned with ethyl acetate and water (1:1), yielded an ethyl acetate fraction of $4.62 \mathrm{~g}(9.24 \%)$; the residue was partitioned with butanol and water (1:1), yielded a butanol fraction of $2.40 \mathrm{~g}(4.8 \%)$; and the residue was the water fraction of $11.93 \mathrm{~g}(23.86 \%)$ (Soeng et al., 2015).

\section{Phytochemical screening}

The phytochemical assay was conducted on $C$. mangga ethanol extract (CME) using a modified Fransworth method to qualitatively identify the presence of phenols, saponins, steroid/triterpenoids, terpenoids, tannins, flavonoids, and alkaloids (Adnyana et al., 2016).

\section{Phenolic compound identification}

A sample (10 mg) was placed on a dropping plate, then $1 \% \mathrm{FeCl}_{3}$ (Merck 1.03861.0250, USA) was added into the sample. The colour formation of green/red/purple/blue/black showed the presence of phenolic contents (Widowati et al., 2016; Adnyana et al., 2016).

\section{Saponin compund identification}

Ten miligram of a sample was put into the test tube with some water and boiled for $5 \mathrm{~min}$, and then shaken vigorously. Saponin content was indicated 
by persistence of froth on the surface (Adnyana et al., 2016).

\section{Steroid/triterpenoid compound identification}

Approximately $10 \mathrm{mg}$ of a sample was put on a dropping plate, then soaked with acetate acid until the sample was covered. After 10-15 min, one drop of absolute sulphate acid $\left(\mathrm{H}_{2} \mathrm{SO}_{4}\right)$ (Merck 109073, USA) was added into the sample. The presence of steroid was indicated by formation of green/blue colour. Triterpenoid was indicated by red/orange sediment (Widowati et al., 2016; Adnyana et al., 2016).

\section{Terpenoid compound identification}

Approximately $10 \mathrm{mg}$ of a sample was added into a dropping plate, then vanillin and $\mathrm{H}_{2} \mathrm{SO}_{4}$ were added into the sample. The formation of purple colour on the mixture showed positive reaction of terpenoid compounds (Widowati et al., 2016; Adnyana et al., 2016).

\section{Tannin compound identification}

Approximately $10 \mathrm{mg}$ of a sample was added with $2 \mathrm{~mL}$ of $\mathrm{HCl} 2 \mathrm{~N}$ (Merck, 1003171000) into a test tube. Briefly, the mixture was heated for $30 \mathrm{~min}$ on a water bath. Afterwards, the mixture was cooled down and filtered. Subsequently, the filtrate was added with amyl alcohol (Merck, 10979). Tannins were indicated by purple colour formation (Widowati et al., 2016; Adnyana et al., 2016).

\section{Flavonoid compound identification}

A sample $(10 \mathrm{mg})$ was added into a test tube, then $\mathrm{HCl} 2 \mathrm{~N}$ and $\mathrm{Mg}$ (Merck, EM105815) was also added. The mixture was heated for 5 to $10 \mathrm{~min}$ then cooled down and filtered. Amyl alcohol was added into the filtrate. The formation of red or orange colour indicated the presence of flavonoids (Adnyana et al., 2016).

\section{Alkaloid compound identification}

Ten miligram of a sample was introduced into a test tube, then $10 \%$ ammonia was added into the sample. Chloroform (Merck 1.024.452.500, USA) was added to the mixture, so it formed two layers of liquid and the bottom layer was collected. $\mathrm{HCl} 1 \mathrm{~N}$ was added to the liquid, forming two layers, and the upper layer collected and added with 1 drop to 2 drops of draggendorf solution. The positive result was indicated by the presence of yellow colour (Adnyana et al., 2016).

\section{DPPH scavenging activity}

Fifty $\mu \mathrm{L}$ of samples/extract and acarbose (as a positive control) with various levels (400.00; 200.00; $100.00 ; 50.00 ; 25.00 ; 12.50 ; 6.25 \mu \mathrm{g} / \mathrm{mL}$ ) was added in to 96 -well microplates and $200 \mu \mathrm{L}$ of $0.077 \mathrm{mmol}$ 2,2-Diphenyl-1-picrylhydrazil (DPPH) solution (Sig- ma, D9132) in dimethyl sulfoxide (DMSO) (Merck, 1.029.521.000) was added. DMSO (250 $\mu \mathrm{L})$ was added in blank well, for control, $250 \mu \mathrm{L}$ of 0.077 mmol DPPH was added in control well. The plate was incubated in a dark room for $30 \mathrm{~min}$ at room temperature. Absorbance was measured using a microplate reader (Multiskan ${ }^{\mathrm{TM}} \mathrm{GO}$ Microplate Spectrophotometer, Thermo Scientific, Waltham, MA, USA) at $517 \mathrm{~nm}$ (Widowati et al., 2016). The DPPH scavenging activity (\%) was calculated as follows:

$$
\text { DPPH Scavenging Activity }(\%)=\frac{A c-A s}{A c} \times 100
$$

where, $\mathrm{As}=$ sample absorbance, $\mathrm{Ac}=$ negative control absorbance (without sample).

\section{ABTS-reducing activity assay}

ABTS reducing activities were measured using 2,2'-Azinobis-(3-ethylbenzothiazoline-6-sulfonicacid) $($ ABTS•+) (Sigma, A1888-2G) diammonium salt-free radical assay (Widowati et al., 2014) (Widowati et al., 2016). ABTS•+ solution was produced by reacting $14 \mathrm{mM} \mathrm{ABTS}$ and $4.9 \mathrm{mM}$ potassium persulfate (Merck, EM105091) (1:1 volume ratio) for $16 \mathrm{~h}$ in dark condition at room temperature, then the mixture was diluted with $5.5 \mathrm{mM}$ Dulbecco's Phospate Buffer Saline (DPBS) (pH 7.4) (Gibco, 1740576) until the absorbance of the solution was $0.70 \pm 0.02$ at wavelength $745 \mathrm{~nm}$. In brief, $2 \mu \mathrm{L}$ of various levels of samples $(20.00 ; 10.00 ; 5.00 ; 2.50 ; 1.25 ; 0.625$; $0.3125 \mu \mathrm{g} / \mathrm{mL}$ ) were added to each well at 96 -well microplate, then the fresh $198 \mu$ ABTS $\cdot+$ solution were added into the samples. The absorbance was measured at $745 \mathrm{~nm}$ after the plate incubated for 6 $\min$ at $30^{\circ} \mathrm{C}$. The percentage inhibition of ABTS radical $(\%)$ was determined by the ratio of reducing of ABTS $\bullet+$ absorbance in the presence of the sample relative to the absorbance in the absence of the sample (negative control). The median Inhibitory Concentration $\left(\mathrm{IC}_{50}\right)$ were also calculated (Widowati et al., 2016; Etoundi et al., 2010).

\section{The $\alpha$-Amylase inhibitory activity assay}

The $\alpha$-amylase inhibitory activity assay using a modified method (Gondokesumo et al., 2017). Starch $1 \%(20 \mu \mathrm{L})$, buffer sodium phospate $(20 \mu \mathrm{L})$, and samples $(10 \mu \mathrm{L})$ in various levels (133.33; $66.67 ; 33.33 ; 16.67 ; 8.33 ; 4.17 ; 2.08 \mu \mathrm{g} / \mathrm{mL}$ ) were added into sample well, DMSO was used as a blank, incubated at $37^{\circ} \mathrm{C}$ for $3 \mathrm{~min}$. After preincubation, 10 $\mu \mathrm{L}$ of alpha amylase enzymes (Sigma, A7595) was added into each well, except for blank well. The mixture was incubated at $37^{\circ} \mathrm{C}$ for $15 \mathrm{~min}$. Enzymatic reaction was stopped by adding acidic iodine solution in each well. The absorbance was measured at $565 \mathrm{~nm}$ wavelength. The inhibition percentage of $\alpha$ amylase was calculated according to the equation 1 . 
$\%$ Inhibition $=\frac{C-S}{C} \times 100$

where, $\mathrm{C}=$ Absorbance of control, $\mathrm{S}=$ Absorbance of sample.

\section{Statistical analysis}

Data was presented as mean \pm standard deviation. To compare treatments, analysis of variance (ANOVA) was used, and $P<0.05$ was considered as statistically significant, along with Duncan Post-Hoc Test significant and 95\% confidence interval. The median inhibitory concentration $\left(\mathrm{IC}_{50}\right)$ was measured to determine the inhibit ory activies of $\alpha / \beta-g l u-$ cosidase, $\alpha$-amylase, according to linear regression. SPSS version 20.0 program was used for statistical analysis.

\section{RESULTS AND DISCUSSIONS}

\section{Phytochemical screening extract and fractions of C. mangga}

Phytochemical screening extract and fractions of $C$. mangga were shown in Table 1. Based on Table 1, steroids were not detected in all fractions of C. mangga, while triterpenoids were abundant in $\mathrm{HCM}$ and EACM. HCM had high content of terpenoids, BCM had high content in alkaloids. Phenolic content was a little in $\mathrm{CME}$ and $\mathrm{BCM}$, while in others was not detected. Phenols, saponins, and tannins were not detected in HCM and EACM. CME and BCM had all contents except steroids. However, $\mathrm{BCM}$ had higher contents compared to $\mathrm{CME}$, based on this qualitatively method. Phenolic compounds are considered as a major group of compounds that contributes to the antioxidant activities of botanical materials because of their scavenging ability on free radicals due to their hydroxyl groups (Wenzig et al., 2008).

Plants which contain elevated levels of phenols are considered a good source of antioxidants and therefore it is important to quantify phenolic and fla- vonoid contents in plant extracts as they might have many advantageous effects on health (Gulati et al., 2012). Some bioactive compounds from different plants such as $C$. mangga have a hypoglycemic effect through inhibition of $\alpha$-amylase, in that mostly phenolics, triterpenoids, and flavonoids have a potential as antidiabetic agents (Tundis et al., 2010) (Brahmachari et al., 2011). In other study, some phenolic and flavonoid compounds were reported to be effective on human $\alpha$-amylase inhibitors (Matsui et al., 2001).

\section{ABTS-reducing activity}

ABTS-reducing activities of extract and fractions of $C$. mangga, butylated hydroxytoluene, and acarbose are shown in Figure 1 and Table 2. Based on Figure 1, BHT had the highest activity (64.33\%) compared to the other fractions and $C$. mangga extract. Acarbose had the lowest activity with persentation of $8.92 \%$. Among all fractions of $C$. mangga extract, the highest activity was BCM (38.65\%). Based on Table 2, BHT had the lowest $\mathrm{IC}_{50}$ value $(14.02 \pm 0.13 \mu \mathrm{g} / \mathrm{mL})$ compared to the other fractions and extract of $C$. mangga. Among all $C$. mangga fractions, $\mathrm{BCM}$ had the lowest $\mathrm{IC}_{50}$ value $(24.23 \pm 2.77 \mu \mathrm{g} / \mathrm{mL})$, while WCM had the highest $\mathrm{IC}_{50}$ value $(127.48 \pm 6.22 \mu \mathrm{g} / \mathrm{mL})$. This indicated that $\mathrm{BCM}$ had the highest activity in reducing of $\mathrm{ABTS}$ compared to WCM.

Table 2. $\quad \mathrm{IC}_{50}$ values of ABTS-reducing activity of extract and fractions of $C$. mangga, butylated hydroxytoluene, and acarbose

\begin{tabular}{cc}
\hline Samples & Average of $\mathrm{IC}_{50}(\mu \mathrm{g} / \mathrm{mL})$ \\
\hline BHT & $14.02 \pm 0.13$ \\
CME & $90.65 \pm 6.74$ \\
WCM & $127.48 \pm 6.22$ \\
EACM & $27.37 \pm 2.23$ \\
HCM & $76.27 \pm 13.06$ \\
BCM & $24.23 \pm 2.77$ \\
ACR & $81.20 \pm 5.17$ \\
\hline
\end{tabular}

Note: Data $w$ as presented by mean \pm standard deviation. This research $w$ as conducted in triplicate for each treatment

Table 1. Phytochemical screening extract and fractions of $C$. mangga

\begin{tabular}{lccccc}
\multicolumn{1}{c}{ Contents } & CME & WCM & BCM & HCM & EACM \\
\hline Steroids/Triterphenoids & $-/+$ & $-/+$ & $-/+++$ & $-/+++++$ & $-/++++$ \\
Terphenoids & ++ & + & ++ & ++++ & +++ \\
Phenols & + & - & + & - & - \\
Saponins & ++ & ++ & ++ & - & - \\
Tannins & +++ & + & ++ & - & - \\
Flavonoids & + & ++ & ++ & + \\
Alkaloids & + & - & ++++ & ++ \\
Note: $+++++=$ very high content; ++++= high content; +++ = moderate content; ++= low content, += very low content; $-=$ not \\
detected CME= C. mangga Extracts; WCM= Water fraction of C. mangga; BCM= Butanol fraction of C. mangga; HCM= \\
Hexane fraction of C. mangga; EACM= ethyl acetate fraction of C. Mangga
\end{tabular}




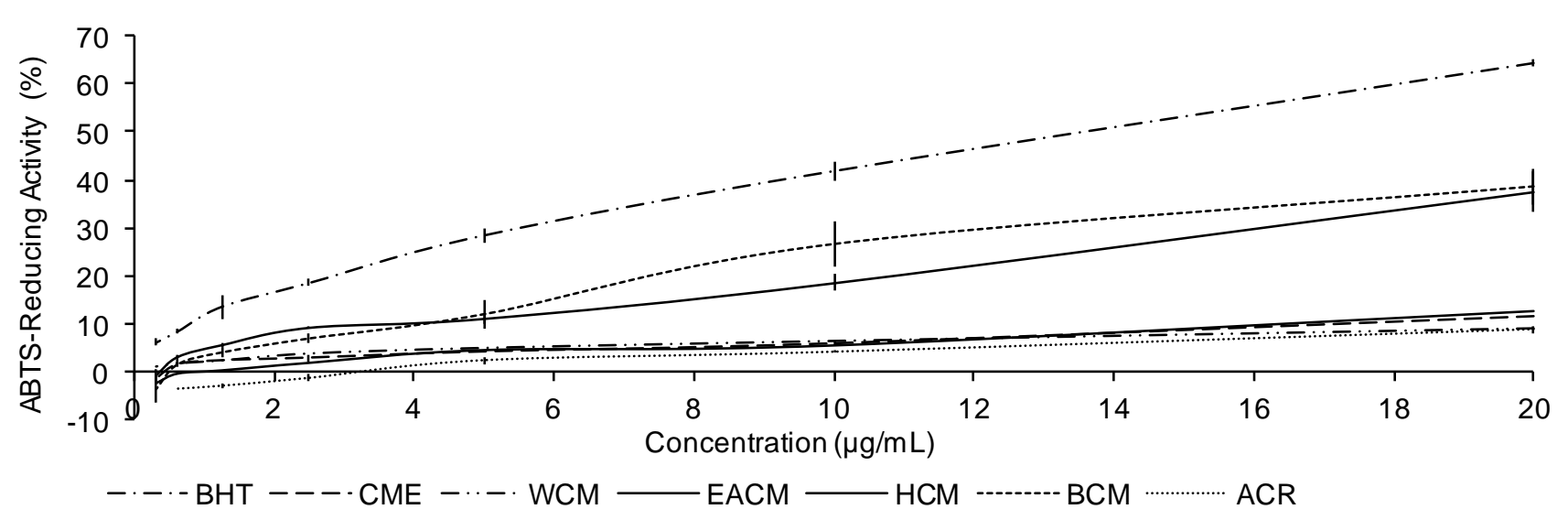

Note: This research $w$ as conducted in triplicate for each treatment

Figure 1. ABTS-reducing activity of extract and fractions of C. mangga, butylated hydroxytoluene, and acarbose

In other study, flavonoids in C. mangga rhizome extracts had antioxidant activity that can act as a free radical scavenger (ROS) caused by aloxan (Madihah et al., 2016). Polyphenols such as flavonoids had free radical scavenging activity and can decrease oxidative stress (Patel et al., 2011). Butanols in $C$. mangga fraction (BCM) had the highest content compared to $\mathrm{CME}$ based on this qualitatively method (Table 1). Butanol fraction exhibited strong antioxidant activities in ABTS, FRAP and DPPH assays compared to other fractions and extracts (Jaitak et al., 2010). BCM had a lot of compounds, this might affect in ABTS reducing activity. Butyl Hidroxy Toluen (BHT) is a syntethic antioxidant that has a side effect by producing toxins or acting as a carcinogen (Shasha, 2014), therefore BCM has a potential to be a source of natural antioxidants that can be useful as an alternative of syntethic antioxidants. Other study demonstrated that phenolic compounds were contributors to the antioxidant activity in the plants. Antioxidants could scavenge free radicals which contributed to the pathogenesis of DM (Angel et al., 2013).

\section{DPPH scavenging activity}

DPPH scavenging activities of extract and fractions of C. mangga, butylated hydroxytoluene, and acarbose were presented in Figure 2 and Table 3. Based on Figure 2, the highest persentation was BHT $(92.72 \%)$ that slightly comparable with EACM $(92.69 \%)$. Among all C. mangga fractions, EACM had the highest activity compared to the other fractions. The lowest DPPH scavenging activity was Acarbose (ACR) (25.66\%). This indicated that EACM also had good antioxidant activities. Based on Table 3, BHT, as a marker compound, had the lowest $\mathrm{IC}_{50}$ value $(76.55 \pm 2.84 \mu \mathrm{g} / \mathrm{mL})$, while $A C R$ had the highest $I_{50}$ value of $1102.35 \pm 79.17 \mu \mathrm{g} / \mathrm{mL}$. Among all $C$. mangga fractions, EACM had the lowest $\mathrm{IC}_{50}$ value $(83.95 \pm 2.89 \mu \mathrm{g} / \mathrm{mL})$ compared to the other fractions. Overall, EACM had the highest DPPH scavenging activity compared to the other compounds and $C$. mangga fractions. Based on the DPPH scavenging activity, EACM had less activity compared to BHT. This indicated that the fractions of C. mangga, especially EACM had good antioxidants compared to CME. In other study, C. mangga with blanching method had higher DPPH scavenging activity compared to $C$. mangga fresh rhizome in all solvent (Pujimulyani et al., 2010).

Flavonoid compounds in C. mangga may be able to repair body in various mechanisms, one way is by increasing catalase enzymes to break down peroxide hydrogen to become oxygen and water that are not dangerous in cells and cell growth. Flavonoid exposure in cells can decrease ROS by restoring cell integrity and increasing the viability of a cell (Patel, 2008). The repairment of pancreas histological structure was thought to be due to the flavonoid compounds contained in the rhizome extract of $C$. mangga that were able to bind and reduce the amount of ROS, the cause of necrosis in pancreatic $\beta$ cells (Madihah et al., 2016). The ethyl acetate solvents were compatible for extracting phenolic compounds (Rohman et al., 2006).

Table 3. $\quad \mathrm{IC}_{50}$ values of DPPH scavenging activity of extract and fractions of $C$. mangga, butylated hydroxytoluene, and acarbose

\begin{tabular}{cc}
\hline Samples & Average of $\mathrm{IC}_{50}(\mu \mathrm{g} / \mathrm{mL})$ \\
\hline BHT & $76.55 \pm 2.84$ \\
CME & $230.94 \pm 11.11$ \\
WCM & $792.73 \pm 86.90$ \\
EACM & $83.95 \pm 2.89$ \\
HCM & $160.28 \pm 5.88$ \\
BCM & $103.38 \pm 4.34$ \\
ACR & $1102.35 \pm 79.17$
\end{tabular}

Note: Data $w$ as presented by mean \pm standard deviation. This research $w$ as conducted in triplicate for each treatment 


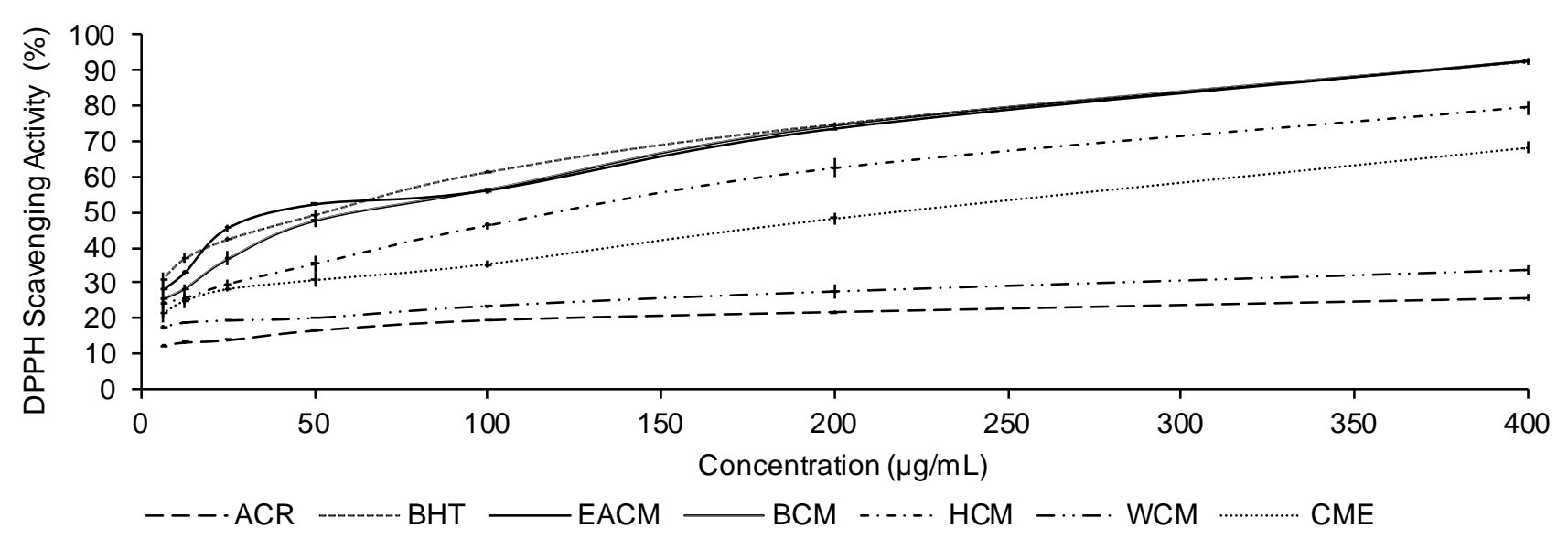

Note: This research $w$ as conducted in triplicate for each treatment

Figure 2. DPPH scavenging activity of extract and fractions of $C$. mangga, butylated hydroxytoluene, and acarbose

\section{Alpha-Amylase inhibitory activity}

Alpha-amylase enzymes that play a role in digestion of starch and glycogen and inhibit these enzymes are a strategy for the treatment of disorders in carbohydrate uptake such as diabetes and obesity (Sales et al., 2012). Alpha-amylase inhibitors are among the drugs that reduce hyperpostprandial blood glucose by inhibiting the hydrolysis of the starch (Gulati et al., 2012).

Alpha-amylase inhibitory activity was found to maximum in water extract followed by ethanol extract and hydroalcohol extract (Kamtekar et al., 2014). Alpha-amylase inhibitory activity of extract and fractions of $C$. mangga and acarbose are presented in Figure 3 and Table 4. Based on Figure 3, CME fraction of $C$. mangga showed the highest inhibition activity in $\alpha$-amylase $(17.10 \%)$, while the lowest value was EACM (0.71\%). CME had high activitiy but not higher than ACR as a positive control $(81.13 \%)$. Acarbose is one such commercial diabetic drug which exerts glycemic control by its $\alpha$-amylase inhibitory activity (Chinese Diabetes Society, 2014). The lowest $I C_{50}$ value was $A C R$ as a control with value of $61.69 \pm 0.71 \mu \mathrm{g} / \mathrm{mL}$. CME also had the lowest value $(363.67 \pm 4.80 \mu \mathrm{g} / \mathrm{mL})$ compared to the other fractions. CME had high inhibitory activity of $\alpha$ amylase but not higher than ACR. In other study, $C$. mangga had moderate activity in inhibition against $\alpha$ glucosidase enzymes with $\mathrm{IC}_{50}$ value of $121.4 \mu \mathrm{g} / \mathrm{mL}$, while the highest activity was $C$. longa $(28.4 \mu \mathrm{g} / \mathrm{mL})$ compared to other Zingiberaceae plants (Hasimun et al., 2016). The $\alpha$-glucosidase and $\alpha$-amylase enzymes played an important role in mechanism of breakdown of oligo and/or disaccharide to monosaccharides (Rhabasa and Chiasson, 2004).
Table 4. $\quad \mathrm{IC}_{50}$ Values of a-amylase inhibitory activity of extract and fractions of $C$. mangga, and acarbose

\begin{tabular}{cc}
\hline Samples & Average of $\mathrm{IC}_{50}(\mu \mathrm{g} / \mathrm{mL})$ \\
\hline CME & $363.67 \pm 4.80$ \\
WCM & $391.78 \pm 8.54$ \\
EACM & $840.83 \pm 5.26$ \\
HCM & $1327.23 \pm 10.92$ \\
BCM & $1944.00 \pm 46.15$ \\
ACR & $61.69 \pm 0.71$ \\
\hline
\end{tabular}

Note: Data $w$ as presented by mean \pm standard deviation. This research $w$ as conducted in triplicate for each treatment

C. mangga was detected having many compounds (quercetin-3-rutinoside and quercetin) that was known to have a potential as a herbal medicine (Pujimulyani et al., 2012). Their medicinal properties were correlated with the presence of phytochemicals such as phenolics in the rhizomes (Angel et al., 2013). The medicinal plants or natural products involved in retarding the absorption of glucose by inhibiting the carbohydrate hydrolyzing enzymes, such as pancreatic amylase. The inhibition of this enzyme delay carbohydrate digestion and prolong overall carbohydrate digestion time, resulting in the reduction in glucose absorption rate and consequently dulling the postprandial plasma glucose rise. Several indigenous medicinal plants had a high potential in inhibiting a-amylase enzyme activity (Prasanth et al., 2001). Although the main purpose of $\alpha$-amylase inhibition was to slow down maltose and glucose production, it could also slow $\alpha$-glucosidase function by eliminating the substrate of this enzyme (Joshi et al., 2015). 


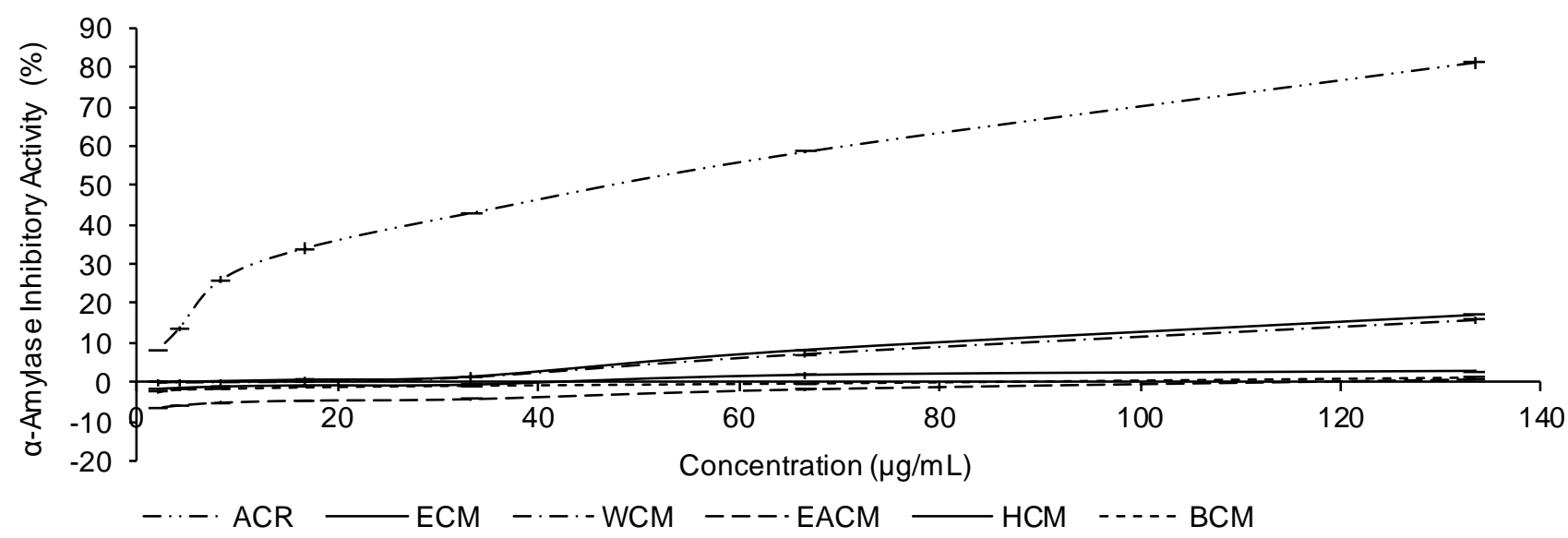

Note: This research $w$ as conducted in triplicate for each treatment

Figure 3. The a-Amylase inhibitory activity of extract and fractions of $C$. mangga and acarbose

Zingiberaceae family (Turmeric) as inhibitors of $\alpha$-glucosidase and $\alpha$-amylase enzyme could be used as phytonutrients to prevent glucose intolerance and obesity causing insulin resistance, especially in populations with a large proportion of carbohydrates consumption. However, C. mangga extracts would be greatly beneficial to reduce the rate of digestion and absorption of carbohydrates and thereby contributed to effective management of diabetes by decreasing the postprandial hyperglycemia (Hasimun, et al., 2016). In other report, the inhibitors of $\alpha$-amylase could delay the breaking down of carbohydrate and diminish the postprandial blood glucose excursion in a person suffering from diabetes (Wulan et al., 2015). It was suggested that $C$. mangga might have a hypoglycemic potential through the inhibition of pancreatic $\alpha$-amylase (Wulan et al., 2015). The mechanism of C. mangga as an inhibitor of $\alpha$ amylase (carbohydrate digesting enzymes), now is actively searching for the medicine against diabetes (Tundis et al., 2010).

The compounds of $C$. mangga might be highly lipophilic and easily cross membranes and exert its pharmacological effects such as inhibiting $\alpha$-amylase enzymes. Curcuma plants like $C$. mangga contained curcuminoids and sesquiter-penoids that showed synergistic antihyperglicemia effectsvia PPAR- $\mathrm{Y}$ activation (Nishiyama et al., 2005). The other result of a study showed that Zingiberaceae plants, $C$. xanthorrhiza and $Z$. cassumunar, had anantihyperglicemia effect by inhibiting $\alpha$-glucosidase enzymes (Hasimun et al., 2016).

\section{CONCLUSIONS}

The fractions of C.mangga had antioxidant properties. BCM and EACM showed the highest antioxidant activities among all fractions as indicated by ABTS activity of $B C M\left(I_{50}=24.23 \mu \mathrm{g} / \mathrm{mL}\right)$ and
DPPH activity of EACM $\left(\mathrm{IC}_{50}=83.95 \mu \mathrm{g} / \mathrm{mL}\right)$. In antidiabetic activity, C. mangga extract showed the highest $\alpha$-amylase inhibitory activity $\left(\mathrm{IC}_{50}=363.67\right.$ $\mu \mathrm{g} / \mathrm{mL}$ ) among all fractions of C. mangga. However, butanol and etyl acetate fractions of $C$. mangga and C. mangga extract exhibited their antioxidant activities and also had antidiabetic effects by inhibiting the $\alpha$-amylase enzymes.

\section{ACKNOWLEDGEMENTS}

We gratefully acknowledge the financial support of Hibah Fundamental 2017 from the Directorate General of Higher Education, The ministry of Research, Technology and Higher Education of the Republic of Indonesia.

\section{REFERENCES}

Adnyana I, Abuzaid A, Iskandar E, Kurniati N. 2016. Pancreatic lipase and $\alpha$-amylase inhibitory potential of mangosteen (Garcinia mangostana Linn.) pericarp extract. Int $\mathrm{J}$ Med Res Health Sci 5: 23-8.

Alam F, Gan SH, Islam MA. 2016. Updates on managing type 2 diabetes mellitus with natural products: towards antidiabetic drug development. Curr Med Chem 23: 1-37. DOI: 10.2174/0 929867323666160813222436.

Angel GR, Vimala B, Nambisan B. 2013. Antioxidant and antiinflammatory activities of proteins isolated from eight Curcuma species. Phyto pharmacol 4: 96-105.

Betteridge DJ. 2000. What is oxidative stress? Metabolism 49: 3-8. 
Brahmachari G. 2011. Bio-Flavonoids with Promising Antidiabetic Potentials: A Critical Survey. In: Tiwari VK, Mishra BB, Editors. Opportunity, Challenge and Scope of Natural Products in Medicinal Chemistry. 187-212. Trivandrum: Research Signpost. Kierala, India.

Chinese Diabetes Society. 2014. Chinese guideline for type 2 diabetes prevention (2013). Chin $\mathrm{J}$ Diabetes 22: 2-42.

Derosa G, Maffioli P. 2012. a-Glucosidase inhibitors and their use in clinical practice. Arch Med Sci 8: 899-906. DOI: 10.5114/aoms.2012.31621.

Etoundi C, Kuat D, Ngondi J, Oben J. 2010. Antiamylase antilipase and antioxidant effects of aqueous extracts of some cameroonian spices. J Nat Products 3: 165-171.

Gondokesumo ME, Kusuma HSW, Widowati W. 2017. $\alpha$-/ $\beta$-glucosidase and $\alpha$-amylase inhibitory activities of roselle (Hibiscus sabdariffa L.) ethanol extract. Mol Cell Biomed Sci 1: 34-40. DOI: $10.21705 /$ mcbs.v1i1.3.

Gulati V, Harding IH, Palombo EA. 2012. Enzyme inhibitory and antioxidant activities of traditional medicinal plants: potential application in the management of hyperglycemia. BMC Complem Altern M 12: 77. DOI: 10.1186/1472-6882-1277.

Hasimun P, Adnyana IK, Valentina R, Lisnasari E. 2016. Potential alpha-glucosidase inhibitor from selected Zingiberaceae family. Asian J Pharm Clin Res 9: 164-167.

Jaitak V, Sharma K, Kalia K, Kumar N, Singh HP, Kaul VK, Singh B. 2010. Antioxidant activity of Potentilla fulgens: An alpine plant of western Himalaya. J Food Compos Anal 23: 142-147. DOI: 10.1016/j.jfca.2009.02.013.

Joshi SRE, Standl E, Tong N, Shah P, Kalra S, Rathod R. 2015. Therapeutic potential of a glucosidase inhibitors in type 2 diabetes mellitus: an evidence-based review. Expert Opin Pharm 16: 1959-1981. DOI: 10.1517/146565 66.2015.1070827.

Kamtekar S, Keer V, Patil V. 2014. Estimation of phenolic content, flavonoid content, antioxidant and alpha amylase inhibitory activity of marketed polyherbal formulation. J Appl Pharmacol Sci 4: 61-65.

Madihah M, Alfina F, Gani YY. 2016. Blood glucose level and pancreas histological section of mice (Mus musculus I.) induced by alloxan after treatment of Curcuma mangga val. Rhizome extract. J Biol 20: 64-68. DOI: 10.24843/JBIO UNUD.2016.v20.i02.p04.
Matsui T, Ueda T, Oki T, Sugita K, Terahara N, Matsumoto K. 2001. a-Glucosidase inhibitory action of natural acylated anthocyanins 1 . Survey of natural pigments with potent inhibitory activity. J Agr Food Chem 49: 1948-1951.

Nishiyama T, Mae T, Kishida $H$, Tsukagawa $M$, Mimaki Y, Kuroda M, Sashida Y, Takahashi K, Kawada T, Nakagawa K, Kitahara M. 2005. Curcuminoids and sesquiterpenoids in turmeric (Curcuma longa L.) suppress an increase in blood glucose level in type 2 diabetic KK-Ay Mice. J Agr Food Chem 53: 959-963. DOI: 10. 1021/jf0483873.

Patel DK, Kumar R, Prasad SK, Sairam K, Hemalatha S. 2011. Antidiabetic and in vitro antioxidant potential of Hybanthus ennea spermus (Linn.) F. Muell in streptozotocin-induced diabetic rats. Asian Pac J Trop Biomed 1: 316-322. DOI: 10.1016/S2221-1691(11)600 51-8.

Patel JM. 2008. A review of potential health benefits of flavonoids. Lethbridge Undergraduate Res $\mathrm{J}$ 3: 32-35.

Prashanth D, Padmaja R, Samiulla DS. 2001. Effect of certain plant extracts on alpha-amylase activity. Fitoterapia 72: 179-181. DOI: 10.101 6/S0367-326X(00)00281-1.

Pujimulyani D, Raharjo S, Marsono Y, Santoso U. 2010. Aktivitas antioksidan dan kadar senyawa fenolik pada kunir putih (Curcuma mangga val.) Segar dan setelah blanching. Agritech 30: 6874.

Pujimulyani D, Raharjo S, Marsono Y, Santoso U. 2010. The effect of blanching treatment on the radical scavenging activity of white saffront (Curcuma mangga Val.). Int Food Res J 17: 615-621.

Pujimulyani D, Raharjo S, Marsono Y, Santoso U. 2012. The effect of blanching on antioxidant activity and glycosides of white saffront (Curcuma mangga Val.). Int Food Res J 19: 617621.

Rhabasa L, Chiasson JL. 2004. Alpha-Glucosidase Inhibitors $3^{\text {rd }}$ Ed. 901-904. John Wiley \& Sons Ltd., UK.

Rohman A, Riyanto S, Utari D. 2006. Aktivitas antioksidan, kandungan fenolik total dan kandungan flavonoid total ekstrak etil asetat buah mengkudu serta fraksi-fraksinya. Majalah Farmasi Indonesia 17: 136-142.

Rotenstein LS, Kozak BM, Shivers JP, Yarchoan M, Close J. 2012. The ideal diabetes therapy: what will it look like? How close are we?. Clin Diabetes 30: 44-53. DOI: 10.2337/diaclin.30.2. 44. 
Sales PM, Souza PM, Simeoni LA, Silveira D. 2012. a-Amylase inhibitors: a review of raw material and isolated compounds from plant source. J Pharm Sci 15: 141-183. DOI: 10.18433/J35 S3K.

Shasha D. 2014. Reversed phase HPLC-UV quantitation of BHA, BHT and TBHQ in food items sold in bindura supermarkets, Zimbabwe. Int Res J Pure Appl Chem 4: 578-584. DOI: 10.97 34/IRJPAC/2014/10419.

Soeng S, Evacuasiany E, Widowati W, Fauziah N, Manik VT, Maesaroh M. 2015. Inhibitory potential of rambutan seeds extract and fractions on adipogenesis in 3T3-L1 cell line. J Exp Integr Med 5: 55-60. DOI: 10.5455/jeim.200115.or.1 20.

Tundis R, Loizzo MR, Menichini F. 2010. Natural products as alpha-amylase and alpha-glucosidase inhibitors and their hypoglycaemic potential in the treatment of diabetes: an update. Mini-Rev Med Chem 10: 315-331. DOI: 10.217 4/138955710791331007.

Wenzig EM, Widowitz U, Kunert O, Chrubasik SF, Bucar E Knauder, Bauer R. 2008. Phytoche- mical composition and in vitro pharmacological activity of two rose hip (Rosa canina L.) Preparations. Phytomedicine 15: 826-835. DOI: 10. 1016/j.phymed.2008.06.012.

Widowati W, Tati H, Hana R, Tjandrawati M. 2011. Antioxidant activities and platelet aggregation inhibitor of black tea (Camellia sinensis L.) extract and fractions. Medicinal Plants 3: 21-26.

Widowati W, Fauziah N, Herdiman H, Afni M, Afifah E, Kusuma HSW. 2016. Antioxidant and anti aging assays of Oryza sativa extracts, vanillin and coumaric acid. J Nat Remed 16: 88-99. DOl: $10.18311 / \mathrm{jnr} / 2016 / 7220$.

Widowati W, Widyanto RM, Husin W, Ratnawati H, Laksmitawati DR, Setiawan B, Nugrahenny D, Bachtiar I. 2014. Green tea extract protects endothelial progenitor cells from oxidative insult through reduction of intracellular reactive oxygen species activity. J Basic Med Sci 17: 702709.

Wulan DR, Utomo EP, Mahdi C. 2015. Antidiabetic activity of Ruellia tuberosa L., role of $\alpha$-amylase inhibitor: in silico, in vitro, and in vivo approaches. Biochem Res Int 2015: 249-261. 